\title{
Prognostic variables in patients with thick melanomas. Analysis of 362 cases
}

\author{
Estefanía Aguilar-Romero, ${ }^{1,2}$ Jazmín D. Chávez-Hernández,, César Zepeda-Najar, ${ }^{3}$ \\ Rosa A. Salcedo-Hernández ${ }^{4}$ and Leonardo S. Lino-Silva ${ }^{1 *}$ \\ ${ }^{1}$ Department of Pathological Anatomy, Instituto Nacional de Cancerología, Mexico City; ${ }^{2}$ AFINES Program, Universidad Nacional Autónoma de \\ México, Mexico City; ${ }^{3}$ Department of Surgical Oncology, Hospital Ángeles Tijuana, Tijuana, Baja California Norte; ${ }^{4}$ Department of Surgical Oncology, \\ Instituto Nacional de Cancerología, Mexico City. Mexico
}

\begin{abstract}
Background: Melanoma epidemiological and prognostic studies are based on Caucasian populations, in whom the predominant subtype is superficially-spreading melanoma and in whom thin melanomas (Breslow $<3 \mathrm{~mm}$ ) predominate. Mexican patients show a predominance of thick melanomas (Breslow $\geq 3 \mathrm{~mm}$ ), and the acral subtype is the most common. There are no publications on prognostic factors in thick melanomas. We hypothesize that we will identify factors that determine the prognosis in this group of patients. Objective: To identify clinical-pathological factors associated with the prognosis of patients with thick melanomas in the Mexican population. Material and methods: Data on melanomas with Breslow $>3 \mathrm{~mm}$ were collected from 2010 to 2015. The prognostic influence of various clinical-pathological factors was analyzed. Results: The most common subtypes were acral melanoma in 271 patients (74.9\%) and nodular melanoma in 49 (13.5\%). Median Breslow thickness was $7 \mathrm{~mm}$. $56.6 \%$ of the patients had lymph node metastases (clinical stage [CS] III), 269 (74.3\%) had ulceration, and surgical margins were positive in 15 (4.1\%). Elevated neutrophil: Iymphocyte ratio ( $\geq 2)$ was found in $188(51.9 \%)$. The variables associated with lower overall survival were CS $(p<0.001)$, Breslow thickness $(p=0.044)$, ulceration $(p=0.004)$, mitotic activity $(p<0.001),<2-c m$ margin $(p<0.001)$ and an increased neutrophil: lymphocyte ratio $(p=0.037)$. In the multivariate analysis, the factors associated with overall survival were CS, mitotic activity, and surgical margin. Conclusions: In patients with thick melanomas, overall survival is influenced by mitotic activity, a positive margin, and clinical stage.
\end{abstract}

KEY WORDS: Melanoma. Breslow. Acral melanoma. Mitotic index. Prognosis.

\section{Variables pronósticas de pacientes con melanomas gruesos. Análisis de 362 casos}

\section{Resumen}

Antecedentes: Los estudios sobre factores pronóstico de melanoma están basados en poblaciones caucásicas, con predominio de melanomas delgados (Breslow $<3 \mathrm{~mm}$ ). Los pacientes mexicanos muestran predominio de melanomas gruesos (Breslow $\geq 3 \mathrm{~mm}$ ). Objetivo: Identificar factores asociados al pronóstico de pacientes con melanomas gruesos. Material y métodos: Se analizó la influencia pronóstica de factores clinicopatológicos en 362 melanomas gruesos. Resultados: La mediana de Breslow fue de 7 mm, 271 (74.9\%) pacientes tuvieron melanoma acral y 49 (13.5 \%) melanoma nodular. El 56.6 \% de los pacientes se encontró en etapa clínica [EC] III), 269 (74.3 \%) tenía ulceración y 15 (4.1\%) márgenes positivos. Las variables asociadas con menor supervivencia global [SG] fueron la EC ( $p<0.001)$, Breslow $(p=0.044)$, ulceración $(p=0.004)$, mitosis $(p<0.001)$ y margen $<2 \mathrm{~cm}(p<0.001)$. En el análisis multivariante los facto-

\footnotetext{
Correspondence: Date of reception: 27-05-2020

*Leonardo S. Lino-Silva Date of acceptance: 16-07-2020

DOI: $10.24875 / G M M . M 21000543$

Gac Med Mex. 2021;157:207-211

Contents available at PubMed

E-mail: saul.lino.sil@gmail.com

www.gacetamedicademexico.com

0016-3813/@ 2020 Academia Nacional de Medicina de México, A.C.. Published by Permanyer. This is an open access article under the CC BY-NC-ND license (http://creativecommons.org/licenses/by-nc-nd/4.0/).
} 
res que influyen en SG fueron la EC, mitosis y el margen quirúrgico. Conclusiones: En pacientes con melanomas gruesos la SG es influida por un margen positive, mitosis y EC.

PALABRAS CLAVE: Melanoma. Breslow. Melanoma acral. Índice mitósico. Pronóstico.

\section{Introduction}

Cutaneous melanoma is a potentially aggressive malignancy the incidence of which continues to increase. In advanced cases, therapeutic options are limited, and there is a continuous search for novel prognostic factors and possible treatment goals. American Joint Committee on Cancer current TNM (Tumor, Node, Metastasis) staging system is based on multivariate survival analyses of nearly 39,000 melanoma patients. ${ }^{1}$ According to these analyses, the most powerful prognostic indicators known in patients with localized melanoma are tumor thickness (Breslow thickness), ulceration, and mitotic count, in that order. However, known studies on these melanoma prognostic factors, as well as epidemiology and clinicopathological characteristics are based on populations of Caucasian origin, in whom the most common melanomas are strongly associated with sun exposure and are predominantly of the superficial dissemination type, in addition to showing a predominance of thin melanomas (Breslow $<3 \mathrm{~mm}$ ).

Mexican melanoma patients have some distinctive clinicopathological differences, such as a predominance of the acral lentiginous subtype, as well as presenting with tumors with higher Breslow thickness. ${ }^{2}$ Given that most patients in our population exhibit these unique clinical and pathological characteristics, and given that they are diagnosed at more advanced pathological stages, it is necessary for factors that allow better discriminating these patients' prognosis to be identified. Although the majority will be diagnosed at advanced pathological stages (pT3 and pT4) and intrinsically could have a poor prognosis, we believe that, even in this group of patients, overall survival may be influenced by pathological factors that allow identifying those patients with a poorer prognosis and thus being able to establish treatment strategies aimed at improving their life expectancy. In the literature, only two studies have explored pathological variables associated with prognosis in patients with thick melanomas; ${ }^{3,4}$ howev$\mathrm{er}$, these are works aimed at finding specific markers (such as tumor-infiltrating lymphocytes) and in Caucasian populations. It is therefore necessary to identify these factors in order to improve patient care, especially in Mexican patients, and this information could be extrapolated to Latin American populations, who share similar genetic backgrounds. The purpose of this work is to identify, in thick melanomas (Breslow $>3 \mathrm{~mm}$ ), clinicopathological factors associated with patient prognosis. Our working hypothesis is that patients with thick melanomas have additional prognostic factors that allow stratifying them in risk groups.

\section{Material and methods}

Data were retrospectively collected from the database of the Department of Pathological Anatomy of our institution, a national reference center. A total of 1,209 patients with histologically-confirmed melanoma diagnosis between 2010 and 2015 who had Breslow thickness $>3 \mathrm{~mm}$ were identified. All patients received full care and follow-up at our institution. Patients with previous treatments, recurrent disease, mucosal melanoma and melanoma in situ, as well as patients without follow-up, were excluded. The remaining 362 patients were analyzed in this study.

Demographic, preoperative, pathological and outcome variables were recorded. Clinical staging was performed by computed tomography, physical examination, and serum lactate dehydrogenase values. All patients were examined every three months for the first two years, and every six months thereafter. The outcome variables were divided as follows: surgery was considered adequate if the melanoma had been removed with appropriate surgical margins (which we defined as adequate if Breslow thickness $>2 \mathrm{~cm}$ ). ${ }^{3}$ The primary outcome of our study was overall survival.

Data were analyzed using the SPSS 24.0 package for Windows (SPSS Inc., Chicago, IL, USA). The relationship between categorical variables was analyzed using the chi-square test, and for numerical variables, Mann-Whitney's U-test was used. The estimation of survival cumulative distribution in separate groups was calculated according to the Kaplan-Meier method, with the time of surgery as entry date. Differences in survival observed between the groups were tested using log-rank tests. Multivariate analysis was carried out using the Cox proportional hazards model with 
forward progressive selection. All p-values were two-tailed, with hazard ratios $(\mathrm{HR})$ and their corresponding $95 \%$ confidence intervals $(\mathrm{Cl})$.

\section{Results}

Data from 1,219 patients are summarized in table 1; 713 patients $(58.5 \%$ ) were females, and median age was 57 years (range, 15-92). Most common clinicopathological subtypes were acral lentiginous melanoma in 271 patients $(74.9 \%)$ and nodular melanoma in 49 (13.5\%). Median Breslow thickness was $7 \mathrm{~mm}$. The most common Breslow group was that of lesions between 4 and $7 \mathrm{~mm}$. All patients had sentinel lymph nodes and, out of them, $56.6 \%$ had metastases. Ulceration was present in 269 patients $(74.3 \%)$, and surgical margins were inadequate in 15 (4.1\%). The most common clinical stage was stage III. Elevated neutrophil: lymphocyte ratio $(\geq 2)$ was found in 188 patients (51.9\%).

In the univariate survival analysis (Table 2), the variables that were identified to be statistically associated with lower overall survival were clinical stage $(p<0.001)$, positive sentinel lymph node $(p<0.001)$, Breslow thickness $(p=0.044)$, ulceration $(p=0.004)$, presence of mitotic activity $(p<0.001)$, inadequate margin $(p<0.001)$ and increased neutrophil: lymphocyte ratio $(p=0.037)$. In the multivariate analysis (Table 3), the factors that proved to be independently-associated with overall survival were clinical stage, mitotic activity, and surgical margin.

\section{Discussion}

In this study of 362 patients with thick melanomas, we identified that the most common subtype was acral melanoma and that the factors that were independently associated with overall survival were clinical stage, mitotic activity, and surgical margin. The univariate analysis showed that Breslow depth continues to be an important predictor of survival, with survival decreasing as Breslow thickness increases. In addition, an increased neutrophil: Iymphocyte ratio was identified to decrease overall survival.

To the best of our knowledge, studies of prognostic markers in thick cutaneous melanoma are quite limited. ${ }^{4,5}$ In cutaneous melanoma evaluation, microscopic characteristics are crucial, not only for diagnosis but also for prognosis, including tumor thickness, ulceration and mitotic count, according to the latest TNM classification. Despite current knowledge on prognostic indicators in cutaneous melanoma, patient
Table 1. Clinical and pathological variables of $\mathbf{3 6 2}$ patients with melanoma

\begin{tabular}{|c|c|}
\hline Variable & Values \\
\hline Age (years), median (range) & $58(18-73)$ \\
\hline $\begin{array}{l}\text { Age groups, } n(\%) \\
<40 \text { years } \\
\geq 40 \text { years }\end{array}$ & $\begin{array}{c}40(11) \\
322(89)\end{array}$ \\
\hline $\begin{array}{l}\text { Gender, n (\%) } \\
\text { Females } \\
\text { Males }\end{array}$ & $\begin{array}{l}207(57.2) \\
155(42.8)\end{array}$ \\
\hline $\begin{array}{l}\text { Clinical stage, n (\%) } \\
\text { II } \\
\text { III }\end{array}$ & $\begin{array}{l}157(43.4) \\
205(56.6)\end{array}$ \\
\hline $\begin{array}{l}\text { Subtypes, } n(\%) \\
\text { Acral } \\
\text { Nodular } \\
\text { Superficial dissemination }\end{array}$ & $\begin{array}{l}271(74.9) \\
49(13.5) \\
42(11.6)\end{array}$ \\
\hline Breslow thickness, mm, median (range) & $7(3-60)$ \\
\hline $\begin{array}{l}\text { Thickness groups (Breslow), } \mathrm{n}(\%) \\
3-4 \mathrm{~mm} \\
4.1-7 \mathrm{~mm} \\
7.1-10 \mathrm{~mm} \\
>10 \mathrm{~mm}\end{array}$ & $\begin{array}{l}93(25.7) \\
119(32.9) \\
62(17.1) \\
88(24.3)\end{array}$ \\
\hline $\begin{array}{l}\text { Ulceration, n (\%) } \\
\text { No } \\
\text { Yes }\end{array}$ & $\begin{array}{c}93(25.7) \\
269(74.3)\end{array}$ \\
\hline Mitosis, median (range) & $0(0-60)$ \\
\hline $\begin{array}{l}\text { Mitosis, } n(\%) \\
\leq 1 \text { mitosis } \\
>1 \text { mitosis }\end{array}$ & $\begin{array}{l}225(62.2) \\
137(37.8)\end{array}$ \\
\hline $\begin{array}{l}\text { Surgical margin, } \mathrm{n}(\%) \\
\text { Adequate } \\
\text { Inadequate }(<2 \mathrm{~cm})\end{array}$ & $\begin{array}{c}347(95.9) \\
15(4.1)\end{array}$ \\
\hline Longest diameter, mm, median (range) & $26(1-190)$ \\
\hline Neutrophil:Iymphocyte ratio, median (range) & $2(0.58-17)$ \\
\hline $\begin{array}{l}\text { Neutrophil:Iymphocyte ratio, } n(\%) \\
<2 \\
\geq 2\end{array}$ & $\begin{array}{l}174(48.1) \\
188(51.9)\end{array}$ \\
\hline Average follow-up, median (standard deviation) & $41.12(39)$ \\
\hline $\begin{array}{l}\text { Outcome, n (\%) } \\
\text { Alive } \\
\text { Dead }\end{array}$ & $\begin{array}{c}264(72.9) \\
98(27.1)\end{array}$ \\
\hline 5-year overall survival (\%) & $66.9 \%$ \\
\hline
\end{tabular}

outcomes can be unpredictable. Distant metastases can appear in cases with thick primary tumors with no other known unfavorable prognostic characteristics; in contrast, no recurrence or death can be observed in cases of thick primary tumors at long-term follow-up. 
Table 2. Clinical variables associated with survival in $\mathbf{3 6 2}$ melanoma patients

\begin{tabular}{|c|c|c|c|}
\hline Variable & $\begin{array}{l}\text { Mean survival } \\
\text { (months) }\end{array}$ & $\begin{array}{c}\text { 5-year overall } \\
\text { survival }\end{array}$ & p-value \\
\hline $\begin{array}{l}\text { Gender } \\
\text { Males } \\
\text { Females }\end{array}$ & $\begin{array}{l}110.5 \\
93.7\end{array}$ & $\begin{array}{l}61.2 \\
70.2\end{array}$ & 0.523 \\
\hline $\begin{array}{l}\text { Age } \\
<40 \text { years } \\
\geq 40 \text { years }\end{array}$ & $\begin{array}{l}126.4 \\
104.4\end{array}$ & $\begin{array}{l}74.9 \\
65.8\end{array}$ & 0.144 \\
\hline $\begin{array}{l}\text { Clinical stage } \\
\text { IIA } \\
\text { IIB } \\
\text { IIC } \\
\text { IIIA } \\
\text { IIIB } \\
\text { IIIC }\end{array}$ & $\begin{array}{c}106.857 \\
139.230 \\
103.028 \\
89.919 \\
110.367 \\
75.370\end{array}$ & $\begin{array}{l}85.7 \\
85.7 \\
69.6 \\
78.4 \\
77.8 \\
67.2\end{array}$ & $<0.001$ \\
\hline $\begin{array}{l}\text { Subtype } \\
\text { Acral } \\
\text { Nodular } \\
\text { Superficial } \\
\text { dissemination }\end{array}$ & $\begin{array}{l}103.8 \\
128.5 \\
107.2\end{array}$ & $\begin{array}{l}63.4 \\
84.4 \\
71.4\end{array}$ & 0.093 \\
\hline $\begin{array}{l}\text { Sentinel lymph node } \\
\text { Negative } \\
\text { Positive }\end{array}$ & $\begin{array}{c}127 \\
89.4\end{array}$ & $\begin{array}{c}78 \\
57.1\end{array}$ & $<0.001$ \\
\hline $\begin{array}{l}\text { Breslow groups } \\
3-4 \mathrm{~mm} \\
4.1-7 \mathrm{~mm} \\
7.1-10 \mathrm{~mm} \\
>10 \mathrm{~mm}\end{array}$ & $\begin{array}{l}122.818 \\
107.898 \\
82.720 \\
91.613\end{array}$ & $\begin{array}{l}76.9 \\
70.2 \\
54.6 \\
56.7\end{array}$ & 0.044 \\
\hline $\begin{array}{l}\text { Ulceration } \\
\text { No } \\
\text { Yes }\end{array}$ & $\begin{array}{l}\mathrm{NC} \\
\mathrm{NC}\end{array}$ & $\begin{array}{l}82.7 \\
61.9\end{array}$ & 0.004 \\
\hline $\begin{array}{l}\text { Mitosis } \\
\text { No } \\
\text { Yes }\end{array}$ & $\begin{array}{c}121.3 \\
90.0\end{array}$ & $\begin{array}{l}77.3 \\
50.8\end{array}$ & $<0.001$ \\
\hline $\begin{array}{l}\text { Margin } \\
\text { Adequate } \\
\text { Inadequate }(<2 \mathrm{~cm})\end{array}$ & $\begin{array}{l}110.6 \\
27.1\end{array}$ & $\begin{array}{l}68.9 \\
12.9\end{array}$ & $<0.001$ \\
\hline $\begin{array}{l}\text { Neutrophil:lymphocyte } \\
\text { ratio } \\
<2 \\
\geq 2\end{array}$ & $\begin{array}{l}116.1 \\
98.5\end{array}$ & $\begin{array}{l}72.2 \\
61.6\end{array}$ & 0.037 \\
\hline
\end{tabular}

In this context, there is a demand for better prognostic accuracy and more appropriate treatment and follow-up. In our population, as shown by our results, patients generally present with large tumors at advanced stages, where prognosis would appear to be bleak. In existing studies, known prognostic factors are associated with poorer survival. ${ }^{4}$ However, in our patients, ulceration was not associated with poorer prognosis.
Table 3. Multivariate analysis of factors associated with survival in 362 cases of melanoma

\begin{tabular}{|c|c|c|c|}
\hline Variable & $\begin{array}{l}\text { Hazard } \\
\text { ratio }\end{array}$ & $\begin{array}{c}95 \% \text { confidence } \\
\text { interval }\end{array}$ & $p$-value \\
\hline Mitosis ( $\geq 1$ vs. $<1$ ) & 2.491 & $1.644-3.755$ & $<0.001$ \\
\hline Stage (stage II vs. III) & 1.349 & $1.169-1.556$ & $<0.001$ \\
\hline $\begin{array}{l}\text { Neutrophil:lymphocyte ratio } \\
(<2 \text { vs. } \geq 2)\end{array}$ & 1.222 & $0.809-1.846$ & 0.340 \\
\hline $\begin{array}{l}\text { Breslow groups } \\
\text { (4 groups; reference: 3-mm } \\
\text { Breslow) }\end{array}$ & 1.131 & $0.941-1.361$ & 0.190 \\
\hline $\begin{array}{l}\text { Ulceration (absent vs. } \\
\text { present) }\end{array}$ & 0.685 & $0.379-1.237$ & 0.210 \\
\hline $\begin{array}{l}\text { Margin (adequate vs. } \\
\text { inadequate }[<2 \mathrm{~cm}] \text { ) }\end{array}$ & 0.315 & $0.154-0.646$ & 0.002 \\
\hline
\end{tabular}

Interestingly, in the univariate analysis we found that an increased neutrophil: lymphocyte ratio was associated with a poorer prognosis and, although it did not maintain this association in the multivariate analysis, the fact of being a marker associated with inflammation could provide some prognostic information in our patients, perhaps as an indirect marker of the inflammatory response associated with melanoma. ${ }^{6,7}$

Surgical resection with sufficient margin is a component of surgical standard of care for primary cutaneous melanomas susceptible to surgery. Determining the extent of excision has been a considerable focus of analysis since the earliest melanoma descriptions. In 2011, the Swedish Melanoma Study Group and the Danish Melanoma Group published the results of their Scandinavian collaborative trial, which randomized 936 patients with cutaneous melanoma $>2 \mathrm{~mm}$ Breslow thickness to undergo resection with surgical margins of 2 or $4 \mathrm{~cm}$. The authors concluded that resection margins of $2 \mathrm{~cm}$ were sufficient and safe for patients with $>2 \mathrm{~mm}$ thick melanomas. ${ }^{8}$ Our findings confirm this, since even with very large Breslow thicknesses (half of our population has Breslow thickness $>7 \mathrm{~mm}$ ), a negative margin is independently associated with better overall survival ( $\mathrm{HR}=0.315,95 \% \mathrm{Cl}: 0.154-0.646, \mathrm{p}=0.002)$.

The limitations of our study are those inherent to its retrospective nature and to the fact that it is not a population-based study, but rather a study based on a referral center. In this context, there is generally a presentation bias (more advanced disease or recurrence); however, the results were determined only by the evaluation of those patients who were initially treated at the center. 
In conclusion, we identified that, in patients with stage II and III melanomas with Breslow thickness > $3 \mathrm{~mm}$, survival is influenced by mitotic activity, positive margin, and clinical stage (presence of lymph node metastases). Our univariate analysis suggests a role for the neutrophil: lymphocyte ratio in the prognosis of patients with thick melanomas, a role that should be further investigated. A negative margin in this type of patients is associated with a significant increase in overall survival.

\section{Conflict of interests}

The authors declare that they have no conflicts of interest.

\section{Funding}

The authors did not receive any sponsoring to carry out this article.

\section{Ethical disclosures}

Protection of human and animal subjects. The authors declare that no experiments were performed on humans or animals for this research.
Confidentiality of data. The authors declare that no patient data appear in this article.

Right to privacy and informed consent. The authors declare that no patient data appear in this article.

\section{References}

1. Miller R, Walker S, Shui I, Brandtmüller A, Cadwell K, Scherrer E. Epidemiology and survival outcomes in stages II and III cutaneous melanoma: a systematic review. Melanoma Manag. 2020;7(1):MMT39.

2. Lino-Silva LS, Domínguez-Rodríguez JA, Aguilar-Romero JM, Martínez-Said H, Salcedo-Hernández RA, García-Pérez L, et al. Melanoma in Mexico: Clinicopathologic features in a population with predominance of acral lentiginous subtype. Ann Surg Oncol. 2016;23(13):4189ı94.

3. Balch CM, Soong SJ, Smith T, Ross Mi, Uris MM, Karakousis CP, et al. Long-term results of a prospective surgical trial comparing $2 \mathrm{~cm}$ vs. $4 \mathrm{~cm}$ excision margins for 740 patients with $1-4 \mathrm{~mm}$ melanomas. Ann Surg Oncol. 2001;8(2):10108.

4. Ladstein RG, Bachmann IM, Straume O, Akslen LA. Tumor necrosis is a prognostic factor in thick cutaneous melanoma. Am J Surg Pathol. 2012;36(10):1477ロ82.

5. Rao UN, Lee SJ, Luo W, Mihm MC Jr, Kirkwood JM. Presence of tumor-infiltrating lymphocytes and a dominant nodule within primary melanoma are prognostic factors for relapse-free survival of patients with thick (T4) primary melanoma: pathologic analysis of the e1690 and e1694 intergroup trials. Am J Clin Pathol. 2010;133(4):646ロ53.

6. Gimotty PA, van Belle P, Elder DE, Murry T, Montone KT, Xu X, et al. Biologic and prognostic significance of dermal Ki67 expression, mitoses, and tumorigenicity in thin invasive cutaneous melanoma. J Clin Oncol. 2005;23(31):8048056.

7. Haanen JB, Baars A, Gomez R, Weder P, Smits M, de Gruijl TD, et al. Melanoma-specific tumor-infiltrating lymphocytes but not circulating melanoma-specific $T$ cells may predict survival in resected advanced-stage melanoma patients. Cancer Immunol Immunother. 2006;55(4):45108.

8. Ethun CG, Delman KA. The importance of surgical margins in melanoma. J Surg Oncol. 2016;113(3):339ロ45. 